\title{
Similarities Between Protein IIla and Protein IIIb, Two Prominent Synaptic Vesicle-Associated Phosphoproteins
}

\author{
Michael D. Browning, Chi-Kuang Huang, ${ }^{a}$ and Paul Greengard \\ The Rockefeller University, New York, New York 10021
}

\begin{abstract}
Protein Illa $\left(M_{r} 74,000\right)$ and protein IIlb $\left(M_{r} 55,000\right)$ are 2 major phosphoproteins found in mammalian brain. It was previously shown in intact nerve cells that the phosphorylation state of these 2 proteins could be increased by electrical stimulation, by depolarizing agents in the presence of calcium, and by 8-bromo-cAMP. We now report that protein Illa and protein Illb possess significant structural homology, as indicated by immunochemical studies using polyclonal and monoclonal antibodies and by peptide-mapping studies. A quantitative radioimmunoassay using immunolabeling in SDS-polyacrylamide gels has been used to study the tissue distribution and regional and subcellular distribution in the brain of the 2 proteins. The 2 proteins were found only in nervous tissue and the adrenal medulla. Subcellular fractionation studies suggested that both proteins are associated with synaptic vesicles.
\end{abstract}

Considerable evidence indicates that protein phosphorylation has a significant role in mediating or modulating synaptic events (Gispen and Routtenberg, 1982; Rodnight, 1982; Nestler and Greengard, 1984; Browning et al., 1985). Four prominent phosphoproteins are phosphorylated in intact nerve cell preparations by electrical stimulation in the presence of calcium (Nestler and Greengard, 1982; Tsou and Greengard, 1982), by depolarization in the presence of calcium (Forn and Greengard, 1978), and by application of exogenous 8-bromo-cAMP (Forn and Greengard, 1978; Huang et al., 1982). These 4 proteins are synapsin Ia $\left(M_{r}\right.$ $85,000)$, synapsin Ib $\left(M_{r} 80,000\right)$, protein IIIa $\left(M_{r} 74,000\right)$, and protein IIIb $(M, 55,000)$. Synapsin Ia and synapsin Ib have previously been purified and extensively characterized (Ueda and Greengard, 1977; Huttner and Greengard, 1979; DeCamilli et al., 1983a, b; Huttner et al., 1983). The other 2 proteins, proteins IIIa and IIIb, are the subject of the present study.

\section{Materials and Methods}

Materials. CM-cellulose was from Whatman; hydroxylapatite, Bio-Rad; Sephadex G-75 (superfine), Pharmacia; ampholines (pH 6-8 and 3.511), LKB; Staphylococcus aureus V8 protease, Miles. The catalytic sub-

Received May 5, 1986; revised Aug. 15, 1986; accepted Aug. 19, 1986.

This work was supported by National Science Foundation Grant BNS 8418302 to M.B., by Public Health Service Grant MH 39327 to P.G., and by contract (F33615-85-R-4501) to P.G. from the USAF School of Aerospace Medicine, Aerospace Medical Division (AFSC), U.S. Air Force, Brooks Air Force Base, Texas, and by an award from the Environmental Protection Agency, No. CR 810608 to P.G. The U.S. Government is authorized to reproduce and distribute reprints for Governmental purposes notwithstanding any copyright notation thereon.

Correspondence should be addressed to Michael D. Browning, Ph.D., The Rockefeller University, Laboratory of Molecular and Cellular Neuroscience, 1230 York Avenue, New York, NY 10021.

"Current address: Department of Pathology, University of Connecticut Health Center, Farmington, CT 06032.

Copyright (C) 1987 Society for Neuroscience $0270-6474 / 87 / 030847-07 \$ 02.00 / 0$ unit of cAMP-dependent protein kinase was prepared according to Beavo et al. (1974) and was kindly supplied by Dr. Angus Nairn of our laboratory.

Purification of proteins IIIa and IIIb. The procedures used to purify proteins IIIa and IIIb were identical to those previously described (Huang et al., 1982) through the hydroxylapatite step. The material pooled from the hydroxylapatite column was dialyzed against $5 \mathrm{~mm}$ ammonium bicarbonate and lyophilized. This material was reconstituted in a small

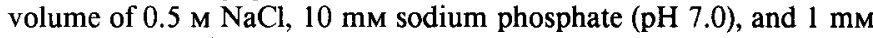
EDTA and applied to a Sephadex G-75 column that had been equilibrated with the same buffer. Proteins IIIa and IIIb eluted together in the void volume.

Separation of protein IIIa from protein IIIb by preparative SDS$P A G E$. Since proteins IIIa and IIIb copurify in the method described above, it was necessary to use preparative SDS-PAGE to separate them from each other so that they could be used as immunogens or as standards in radioimmunoassay (RIA) procedures. For this purpose the protein III purification procedure was followed through the hydroxylapatite step. The material pooled following this step was precipitated with trichloroacetic acid and then solubilized in an SDS Stop Solution [62.5 mM Tris/HCl, pH 6.8; $2.3 \%$ SDS (wt/vol); $10 \%$ glycerol (wt/vol); $5 \% 2$-mercaptoethanol (vol/vol)], boiled for $2 \mathrm{~min}$, and loaded on a $7.5 \%$ SDS-polyacrylamide gel (a trace amount of ${ }^{32} \mathrm{P}$-phosphorylated protein IIIa and protein IIIb was also included). After electrophoresis, protein IIIa and protein IIIb were located by autoradiography of the undried gel and cut from the gel. The gel pieces were finely minced with a razor blade and further minced by being forced through an 18 gauge needle. The material was then incubated with gentle shaking at room temperature in 10 vol distilled water for $12 \mathrm{hr}$. Under these conditions $>70 \%$ of protein IIIa and protein IIIb was extracted from the gel. The mixture was centrifuged at $10,000 \times g$ for $15 \mathrm{~min}$, and the supernatant containing extracted protein IIIa or protein IIIb was dialyzed for $24 \mathrm{hr}$ against 4 changes of $5 \mathrm{~mm}$ ammonium bicarbonate. The dialyzed material was then lyophilized, resuspended in PBS $(150 \mathrm{~mm} \mathrm{NaCl}, 10 \mathrm{~mm}$

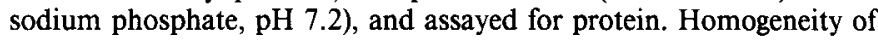
the extracted protein was confirmed by analysis on 2-dimensional nonequilibrium pH gradient electrophoresis (O'Farrell et al., 1977).

Production of polyclonal antisera in rabbits. Young adult female New Zcaland Whitc rabbits werc injected intradermally with $100 \mu \mathrm{g}$ of protein IIIb in complete Freund's adjuvant. The rabbits were given booster injections of $100 \mu \mathrm{g}$ at 3 and 6 weeks after the initial immunization. Antisera were collected starting 2 weeks after the last injection. The specificity of the antisera was determined using immunolabeling in SDSpolyacrylamide gels as described below.

Production of monoclonal antisera. Monoclonal antibodies were prepared essentially as described by Köhler and Milstein (1975). Balb/c mice were immunized with $100 \mu \mathrm{g}$ of homogeneous protein IIIb emulsified in Freund's complete adjuvant by injections into the foot pads and subcutaneous injections over the abdomen. Twelve days after the initial immunization, mice were bled and their sera assayed for the presence of anti-protein IIIb antibodies by testing for immunoprecipitation of ${ }^{125}$ I-IIIb using protein A-bearing Staphylococcus aureus cells as immunoadsorbent. The 2 mice with the highest titcr were boosted $21 \mathrm{~d}$ after the initial immunization with $100 \mu \mathrm{g}$ of protein IIIb in PBS. Three days after this boost, the spleens were removed and the cells manually dissociated. The spleen cells were fused by incubating $10^{8}$ spleen cells with $10^{7} \mathrm{SP} 2 / 0 \mathrm{Ag} 14$ myeloma cells in $50 \%$ polyethylene glycol 1500 (British Drug House) for $5 \mathrm{~min}$ at $37^{\circ} \mathrm{C}$. After the fusion, cells were plated into U-bottom microtiter plates in HT medium (Dulbecco's modified Eagle's medium containing $100 \mu \mathrm{M}$ hypoxanthine, 16 


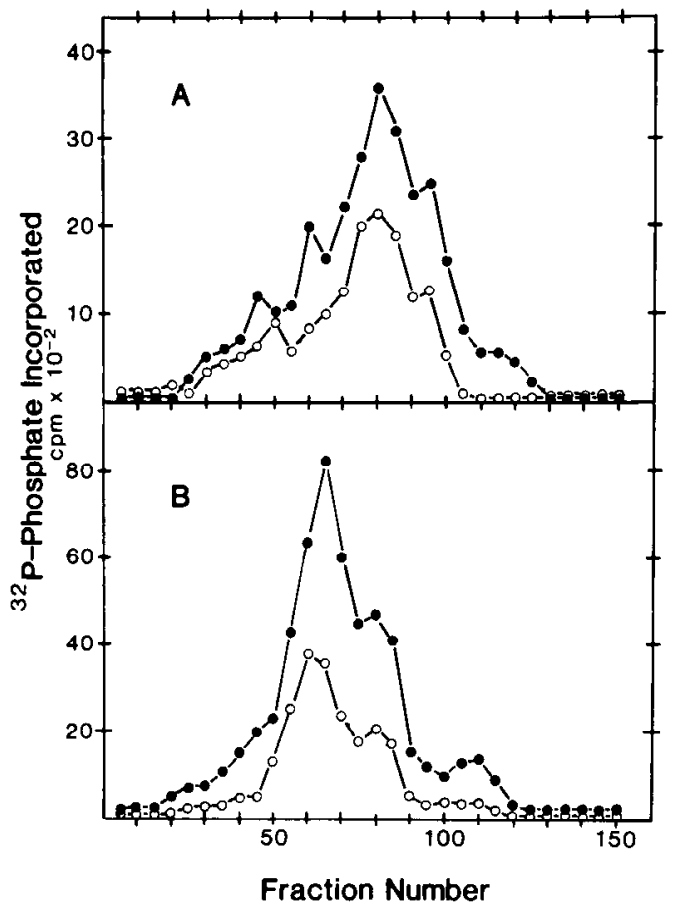

Figure 1. Copurification of proteins IIIa and IIIb on ion-exchange and hydroxylapatite chromatography. $A$, Elution profile of protein IIIa (open circles) and protein IIIb (filled circles) from carboxy-methyl cellulose ion-exchange column. B, Elution profile of protein IIIa (open circles) and protein IIIb (filled circles) from hydroxylapatite column.

$\mu \mathrm{M}$ thymidine, and $15 \%$ fetal calf serum) at a density of $10^{6}$ cells/well in $0.12 \mathrm{ml}$. After $1 \mathrm{~d}$, HA medium (HT medium containing $0.8 \mu \mathrm{M}$ aminopterin) was added to the cultures and then replaced at $3 \mathrm{~d}$ intervals. After 2 changes the cells were fed HT medium every $3 \mathrm{~d}$. Two weeks after fusion, culture supernatants were assayed for ability to immunoprecipitate ${ }^{125}$ I-protein IIIh. Positive cultures were expanded and then cloned by limiting dilution in flat-bottomed microtiter plates using $\mathrm{Balb} / \mathrm{c}$ thymocytes as a feeder layer. Antibody-producing hybrid clones were expanded, and $2 \times 10^{6}$ hybrid cells in HT medium were injected intraperitoneally into animals primed with Pristane (2,6,10,14-tetramethylpentadecane) at least $5 \mathrm{~d}$ earlier. In 2-3 weeks, the ascites that developed was collected by paracentesis. The ascites monoclonal antibody was precipitated with $45 \%$ ammonium sulfate, dialyzed against PBS, and stored in aliquots at $-20^{\circ} \mathrm{C}$.

Iodination of protein IIIb. Protein IIIb was iodinated using chloramine-T as previously described (Goelz et al., 1981).

Standard phosphorylation conditions. Proteins IIIa and IIIb were monitored, during their purification and in other procedures, by their ability to be phosphorylated by the catalytic subunit of cAMP-depen- dent protein kinase. The procedures utilized for phosphorylating proteins IIIa and IIIb were identical to those previously described (Huang et al., 1982).

Two-dimensional gel electrophoresis. Two-dimensional gel electrophoresis (isoelectric focusing followed by SDS-PAGE) was performed as described (O'Farrell, 1975).

One-dimensional peptide maps. One-dimensional peptide mapping was performed essentially as described (Cleveland et al., 1977). Following electrophoresis in a 7.5\% SDS-polyacrylamide gel, the individual phosphorylated or iodinated protein IIIa or protein IIIb bands were localized by autoradiography and cut from the dried gel. The gel pieces were swollen for $1 \mathrm{hr}$ in SDS-Stop Solution. A second SDS-polyacrylamide gel was prepared consisting of a 5-cm-long 5\% acrylamide stacking gel and a $10-\mathrm{cm}$-long $15 \%$ acrylamide separating gel. The gel pieces were pushed to the bottom of the wells of this gel with a spatula and were overlaid with $40 \mu \mathrm{l}$ of a solution containing $0.125 \mathrm{M}$ Tris/ $\mathrm{HCl}(\mathrm{pH}$ $6.8), 0.1 \%$ SDS, and $10 \mu \mathrm{g}$ of $S$. aureus V8 protease. Electrophoresis was performed at $60 \mathrm{~V}$ for $15 \mathrm{hr}$. The gels werc dried without staining and subjected to autoradiography.

Two-dimensional peptide maps. Gel pieces containing phosphorylated protein IIIa or protein IIIb were subjected to exhaustive digestion by trypsin and chymotrypsin, followed by 2-dimensional separation of the resultant peptides as described previously (Huttner et al., 1979).

Detergent-based RIA. The assay procedure was identical to that previously described for synapsin I (Goelz et al., 1981).

Immunolabeling in SDS-polyacrylamide gels. SDS extracts of the tissue samples to be analyzed were subjected to SDS-PAGE. Each gel included several concentrations of either purified bovine protein IIIa and protein IIIb or rat brain cerebral cortex as standard. At the completion of electrophoresis, the gels were fixed in $50 \%$ methanol, $10 \%$ acetic acid, $40 \%$ water $(\mathrm{vol} / \mathrm{vol} / \mathrm{vol})$, and washed in a $\mathrm{NaCl} / \mathrm{Tris} /$ azide buffer containing $150 \mathrm{~mm} \mathrm{NaCl}, 50 \mathrm{~mm}$ Tris/ $\mathrm{HCl}(\mathrm{pH} 7.4), 0.05 \%$ sodium azide (wt/vol) for $3 \mathrm{hr}$ with several changes. The gels were immunolabeled essentially according to Adair et al. (1978). Briefly, the washed gels were incubated in antiserum (1:200 dilution in the $\mathrm{NaCl} /$ Tris/azide buffer, the volume of diluted antisera being twice the volume of the gel) for $12 \mathrm{hr}$ and washed in an excess volume of $\mathrm{NaCl} / \mathrm{Tris} /$ azide buffer for $12 \mathrm{hr}$ with several changes. The gels were incubated with ${ }^{125}$-I-labeled protein $\mathrm{A}\left(2 \times 10^{5} \mathrm{cpm} / \mathrm{ml}\right.$ in the $\mathrm{NaCl} /$ Tris/azide buffer; the volume of the protein A solution was twice the volume of the gel) for $12 \mathrm{hr}$ and washed in an excess volume of $\mathrm{NaCl} / \mathrm{Tris} /$ azide buffer for $24 \mathrm{hr}$ with several changes. The gels were dried, and immunolabeled protein IIIa and protein IIIb bands were identified by autoradiography, cut from the gel, and counted in a Micromedic gamma counter. Homogeneous protein IIIa and protein IIIb were used as standards in determination of the specific activity of protein IIIa and protein IIIb during their purification from bovine brain.

The quantitative tissue distribution, and the regional and subcellular distribution in brain of proteins IIIa and IIIb were studied in rat material obtained immediately after the death of the animal. Because there was a significant difference in avidity of the antibody for the rat and bovine forms of protein IIIb, rat cerebral cortex was chosen as standard for quantitation in all assays of rat tissue. By comparing the ${ }^{125}$ I-protein A labeling of protein IIIa or protein IIIb in the tissue samples of interest to that of protein IIIb in rat cerebral cortex, the relative specific activity of the protein in the tissue relative to protein IIIb in the rat cerebral

Table 1. Purification of proteins IIIa and IIIb

\begin{tabular}{|c|c|c|c|c|c|c|c|}
\hline \multirow[b]{2}{*}{ Purification step } & \multirow{2}{*}{$\begin{array}{l}\text { Protein } \\
(\mathrm{mg})\end{array}$} & \multicolumn{2}{|c|}{$\begin{array}{l}\text { Specific activity } \\
\text { (pmol/mg) }\end{array}$} & \multicolumn{2}{|c|}{ Yield (\%) } & \multicolumn{2}{|c|}{$\begin{array}{l}\text { Purification } \\
\text { (fold) }\end{array}$} \\
\hline & & IIIa & IIIb & IIIa & IIIb & IIIa & IIIb \\
\hline 1. Homogenate & 95,000 & 9 & 19 & 100 & 100 & 1.0 & 1.0 \\
\hline 2. $\mathrm{pH} \mathrm{3-6} \mathrm{extract}$ & 2950 & 110 & 189 & 38 & 31 & 12.2 & 10.0 \\
\hline 3. CM-cellulose, $\mathrm{pH} 8.0$ & 1350 & 108 & 201 & 17 & 15 & 12.0 & 10.6 \\
\hline 4. CM-cellulose, $\mathrm{pH} 6.0$ & 178 & 240 & 507 & 5.0 & 5.0 & 26.6 & 26.7 \\
\hline 5. Hydroxylapatite & 17.3 & 1040 & 1980 & 2.1 & 1.9 & 116 & 104 \\
\hline 6. $\mathrm{G}-75$ & 2.8 & 4570 & 9000 & 1.5 & 1.4 & 508 & 474 \\
\hline
\end{tabular}

Proteins IIIa and IIIb were purified as described in Materials and Methods. The absolute amounts of the proteins were determined using immunolabeling in SDS-polyacrylamide gels (see Materials and Methods). 


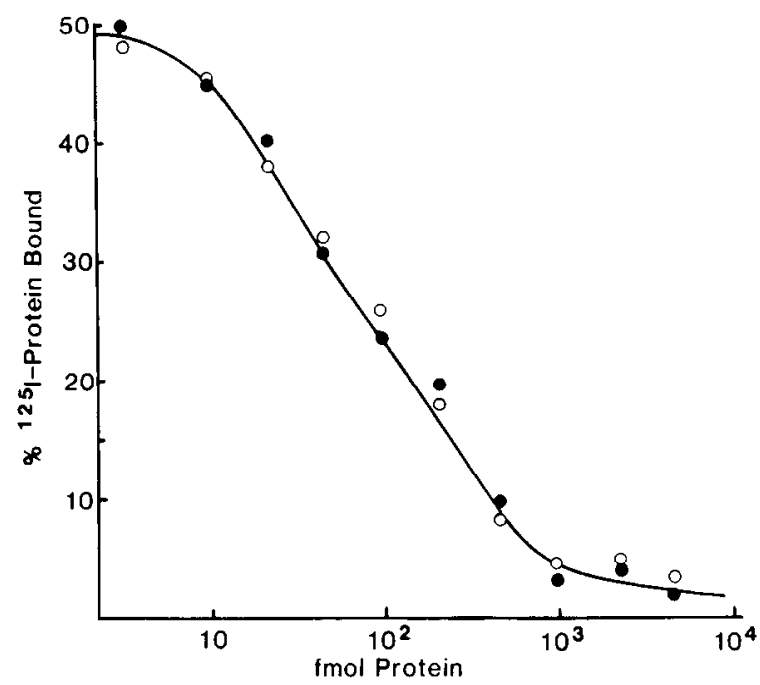

Figure 2. Cross-reactivity of proteins IIIa and IIIb with polyclonal serum. ${ }^{125} \mathrm{I}$-protein IIIB, $1.0 \mathrm{ng}$, was incubated with sufficient antibody to bind $50 \%$ of the iodinated protein. Various amounts of unlabeled protein IIIa (open circles) or protein IIIb (filled circles) were then tested for their ability to displace the ${ }^{125}$ I-protein IIIb from the antibody. Immunoprecipitation was performed as previously described (Goelz et al., 1981).

cortex was obtained. The relative specific activity (RSA) was calculated as follows:

$$
\mathrm{RSA}=\frac{\mathrm{cpm} \mathrm{IIIa} \mathrm{or} \mathrm{IIIb/mg} \mathrm{sample}}{\mathrm{cpm} \mathrm{IIIb} / \mathrm{mg} \text { cortex }} \times 100
$$

Preparation of extracts from various brain regions and various tissues. All brain dissections were performed as described by Walaas et al. (1983). After all brain regions had been dissected (usually within 5 min of sacrifice), tissues were quickly transferred to separate homogenizers containing $1 \% \mathrm{SDS}$ at $90^{\circ} \mathrm{C}$. The tissues were homogenized and returned to $90^{\circ} \mathrm{C}$ for $5 \mathrm{~min}$. In separate experiments in which the cerebral cortex and cerebellum were homogenized within $60 \mathrm{sec}$ of sacrifice, the values obtained for protein IIIa and protein IIIb did not differ significantly from those obtained for these regions when $5 \mathrm{~min}$ had elapsed between sacrifice and SDS homogenization.

Rat tissues were dissected by hand within $5 \mathrm{~min}$ of sacrifice. The tissue was then homogenized in 1\% SDS as described above.

Preparation of subcellular fractions. Purified synaptic vesicle fractions were prepared through the sucrose gradient step as described previously (Huttner et al., 1983). The nuclear, mitochondrial, microsomal, soluble, and synaptic plasma membrane fractions were prepared according to the method of Cotman and Mathews (1971).

\section{Results}

Copurification of proteins Illa and Illb

During the purification of protein IIIb reported previously (Huang et al., 1982), a prominent 74,000 Da phosphoprotein (protein IIIa) was present in all but the final gel-filtration step. In the present study we have measured the amounts of protein IIIa and protein IIIb at each stage of the purification procedure. Protcins IIIa and IIIb copurify throughout the purification procedure (Fig. 1, Table 1). A purification of about 500-fold led to a virtually homogeneous preparation of the 2 proteins.

Comparison of some biochemical properties of proteins Illa and Illb

\section{Studies with polyclonal serum antibodies}

Serum antibodies were raised against protein IIIb that had been purified to homogeneity. One rabbit produced an antibody with

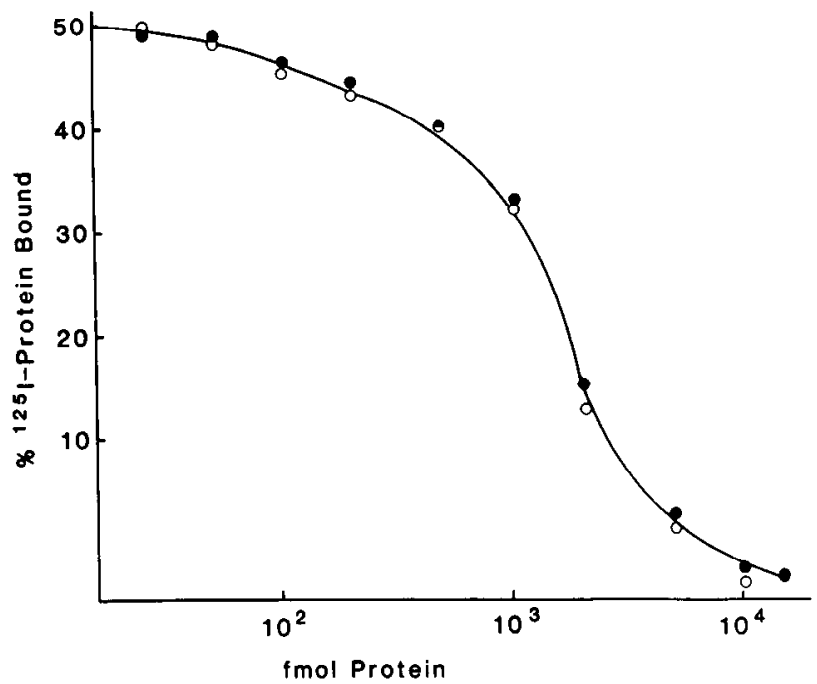

Figure 3. Cross-reactivity of proteins IIIa and IIIb with monoclonal antibody. ${ }^{125}$-protein IIIb, $1.0 \mathrm{ng}$, was incubated with sufficient monoclonal antibody (C19.11) to bind $50 \%$ of the iodinated protein. Various amounts of unlabeled protein IIIa (open circles) or protein IIIb (filled circles) were then tested for their ability to displace the ${ }^{125}$ I-protein IIIb from the antibody. Immunoprecipitation was performed as previously described (Goelz et al., 1981).

sufficient avidity for protein IIIb to permit the development of a detergent-based RIA (Goelz et al., 1981) that was sensitive to as few as $10 \mathrm{fmol}$ protein IIIb. When protein IIIa was examined in this assay, it generated a competition curve that was virtually superimposable on that of protein IIIb (Fig. 2). Each of 10 serum antibodies obtained so far have exhibited essentially $100 \%$ crossreactivity between protein IIIa and protein IIIb (not shown).

\section{Studies with monoclonal antibodies}

In an attempt to obtain antibodies that would differentiate between protein IIIa and protein IIIb, monoclonal antibodies were prepared against protein IIIb. One particular monoclonal antibody (C 19.11) had sufficient avidity for protein IIIb to permit the development of a detergent-based RIA that was sensitive to as few as $20 \mathrm{fmol}$ protein IIIb. When protein IIla and protein IIIb were examined in this RIA, they generated superimposable

\section{Table 2. Tissue distribution of proteins IIIa and IIIb}

\begin{tabular}{lccl} 
& \multicolumn{3}{l}{ Relative specific activity } \\
\cline { 2 - 4 } Tissue & IIIa & IIIb & IIIa/IIIb \\
\hline Cerebral cortex & 48 & 100 & 0.48 \\
Adrenal medulla & 1.7 & 2 & 0.85 \\
Pancreas & $<0.1$ & $<0.1$ & - \\
Spleen & $<0.1$ & $<0.1$ & - \\
Liver & $<0.1$ & $<0.1$ & - \\
Kidney & $<0.1$ & $<0.1$ & - \\
Heart & $<0.1$ & $<0.1$ & - \\
Skeletal muscle & $<0.1$ & $<0.1$ & - \\
Testes & $<0.1$ & $<0.1$ & - \\
Parotid gland & $<0.1$ & $<0.1$ & -
\end{tabular}

Tissues were dissected as described in Materials and Methods and the amount of protein IIIa and protein IIIb determined using immunolabeling in SDSpolyacrylamide gels. For each tissue, the labeling of protein IIIa and protein IIIb per milligram protein was expressed relative to the labeling of protein IIIb in rat cerebral cortex. 
Figure 4. Autoradiogram depicting proteins IIIa and IIIb after separation by 2 -dimensional PAGE. One $\mu \mathrm{g}$ of purified protein IIIa and IIIb was phosphorylated as described in Materials and Methods and subjected to 2-dimensional separation based on isoelectric point (horizontal dimension) and $M$ r (vertical dimension) as previously described (O'Farrell, 1975).
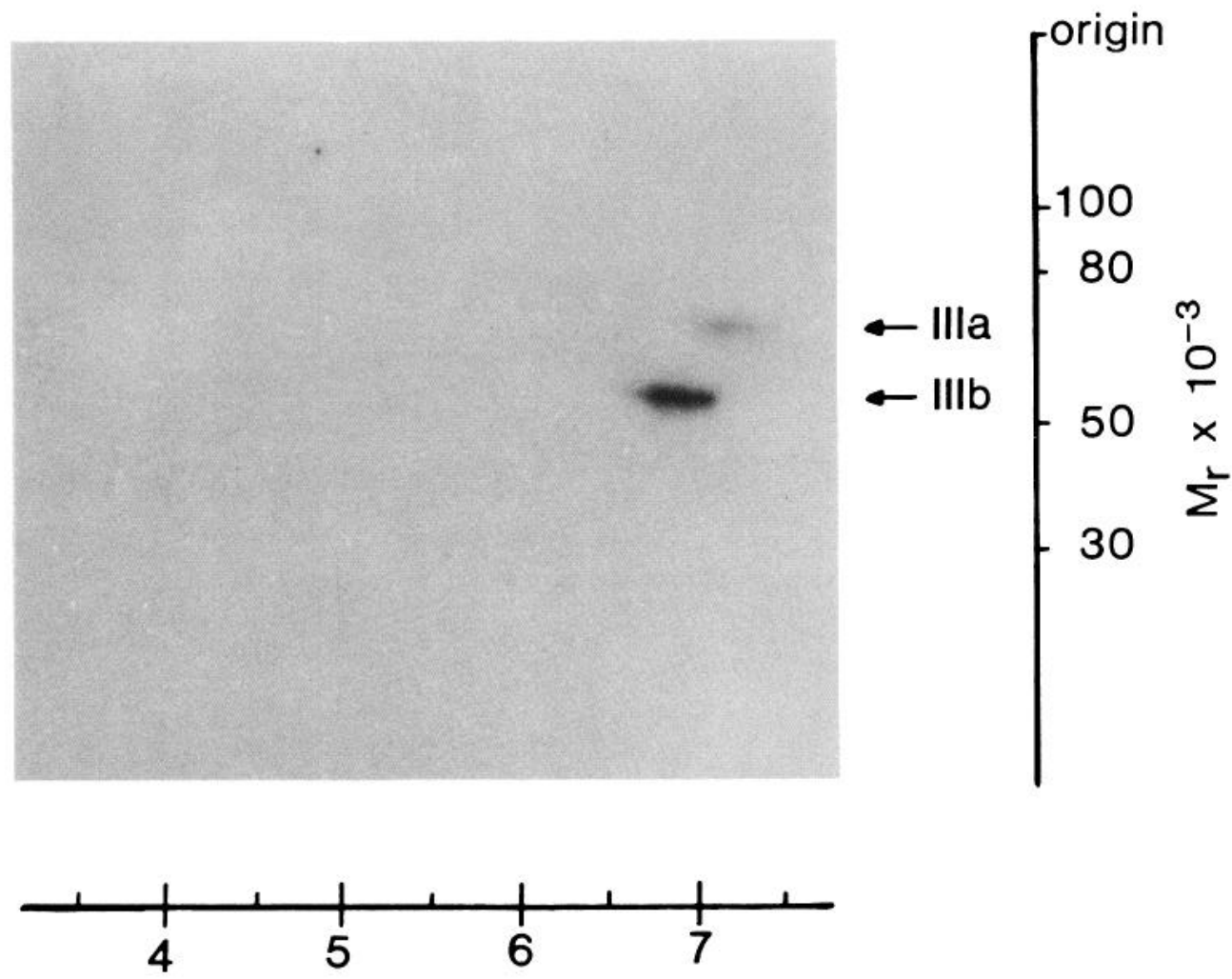

competition curves (Fig. 3). Each of 10 monoclonal antibodies raised against protein IIIb exhibited essentially $100 \%$ crossreactivity toward protein IIIa (not shown).

\section{1-D Peptide Maps}

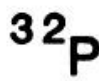

125
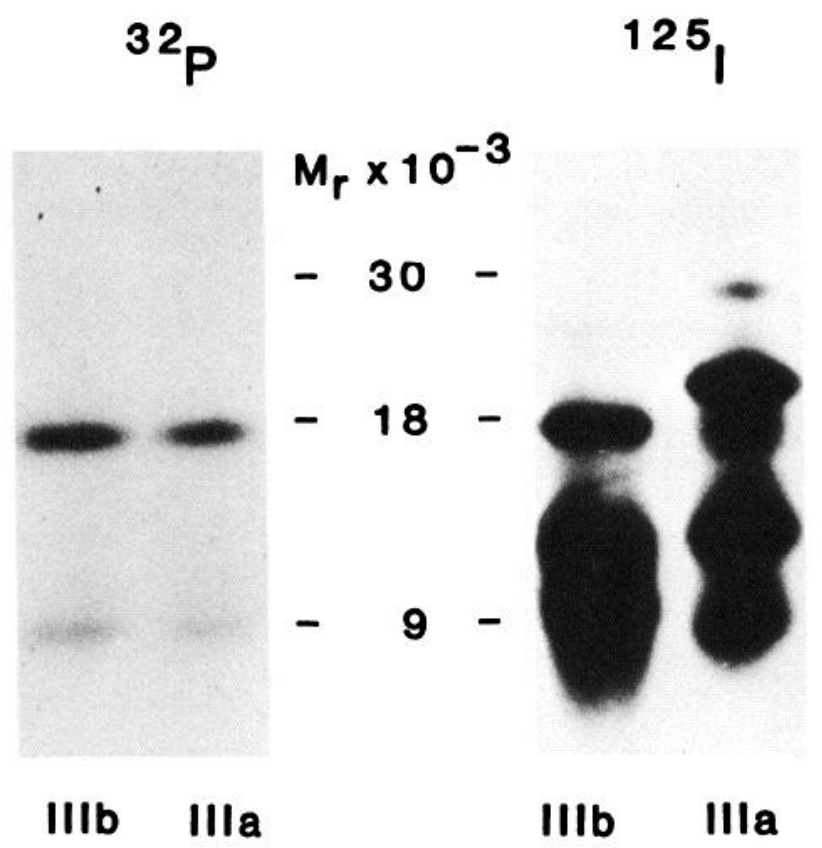

\section{IIIb IIIa}

Figure 5. Autoradiogram depicting one-dimensional peptide maps of proteins IIIa and IIIb. Proteins IIIa and IIIb, which had been phosphorylated (left) or iodinated (right), were subjected to limited proteolysis by $S$. aureus V8 protease in a $15 \%$ polyacrylamide gel as described in Materials and Methods.

\section{Isoelectric focusing}

Using the 2-dimensional technique of O'Farrell (1975), protein IIIa and protein IIIb were compared with respect to their isoelectric points (Fig. 4). The 2 proteins exhibited microheterogeneity. They had similar isoelectric points, with the multiple forms of protein IIIa being slightly more basic $(\mathrm{p} I 6.8-7.1)$ than those of protein IIIb $(\mathrm{p} I$ 6.6-6.9).

\section{One-dimensional peptide maps}

The fragments obtained from partial digestion by $S$. aureus V8 protease of phosphorylated or iodinated protein IIIa or protein $\mathrm{IIIb}$ are compared in Figure 5. Digestion of ${ }^{32} \mathrm{P}$-labeled protein IIIa and protein IIIb yielded a prominent 18,000 Da phosphopeptide fragment and a minor $9000 \mathrm{Da}$ phosphopeptide fragment. Digestion of iodinated protein IIIa and protein IIIb yielded fragments that exhibited only partial homology.

\section{Two-dimensional peptide maps}

A comparison of the 2-dimensional phosphopeptide maps obtained after limit digestion of protein IIIa and protein IIIb by trypsin plus chymotrypsin is shown in Figure 6 . The catalytic subunit of cAMP-dependent protein kinase catalyzed the phosphorylation of only a single peptide in protein IIIa and protein IIIb, which comigrated in the 2-dimensional system used.

\section{Comparison of the distribution of proteins IIla and IIIb}

\section{Immunolabeling in SDS-polyacrylamide gels}

Since proteins IIIa and IIIb exhibited a high degree of crossreactivity with all antibodies tested, it was not possible to use a standard RIA to quantitate the proteins individually. Adair et al. (1978) recently described a technique for immunolabeling proteins in SDS-polyacrylamide gels. We have used this tech- 
Protein IIIb

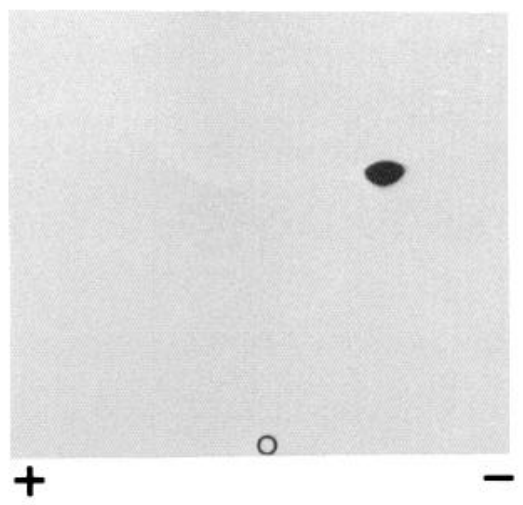

\section{Protein IIIa and IIIb}

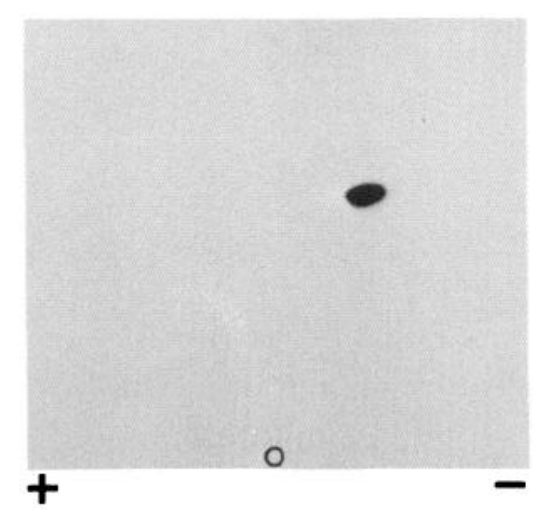

Protein IIIa

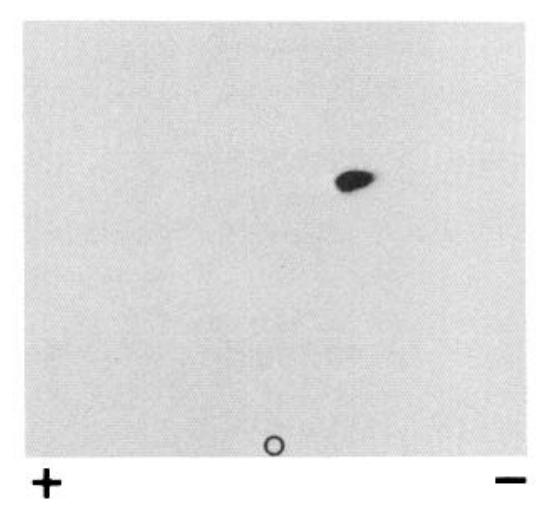

Figure 6. Autoradiogram depicting the phosphopeptide obtained from proteins IIIa and IIIb following limit digestion by trypsin and chymotrypsin. Proteins IIIa and IIIb, which had been phosphorylated by the catalytic subunit of cAMP-dependent protein kinase, were cut from a dried SDS-polyacrylamide gel and subjected to limited digestion by trypsin and chymotrypsin and separated by electrophoresis in the first dimension followed by ascending chromatography in the second dimension (Huttner et al., 1979). In the autoradiogram at the upper left, $600 \mathrm{cpm}$ of digested protein IIIb was applied to the plate. In the autoradiogram at the upper right, $600 \mathrm{cpm}$ of digested protein IIIa was applied to the plate. In the autoradiogram at the bottom, $300 \mathrm{cpm}$ of nique to develop a quantitative assay and have used it for the separate determination of protein IIIa and protein IIIb. The plot of immunolabeling of protein IIIb (Fig. 7) and protein IIIa (not shown) versus amount of rat cerebral cortex homogenate yielded a straight line. We have therefore used immunolabeling in SDS gels to determine the amounts of each of the 2 proteins in a variety of tissue preparations.

\section{Tissue distribution}

Various tissues were examined for the presence of proteins IIIa and IIIb. These proteins could be detected only in brain and the adrenal medulla (Table 2).

\section{Regional distribution in rat brain}

Proteins IIIa and IIIb exhibited similar regional distributions within the CNS (Table 3, Fig. 8). The one notable exception in the distribution patterns of the 2 proteins was the olfactory bulb, which contained relatively higher concentrations of protein IIIa.

\section{Subcellular distribution}

The distributions of proteins IIIa and IIIb in subcellular fractions prepared from rat brain cerebral cortex were essentially identical (Table 4). A substantial enrichment of the proteins was found in a partially purified synaptic vesicle fraction (protein IIIa, 6.6-fold; protein IIIb, 7.0-fold). Of the other fractions examined, only the synaptic plasma membrane fraction and the microsomal fraction exhibited enrichment of either protein IIIa or protein IIIb. However, the enrichment in these fractions was quite modest. each digested protein was applied.

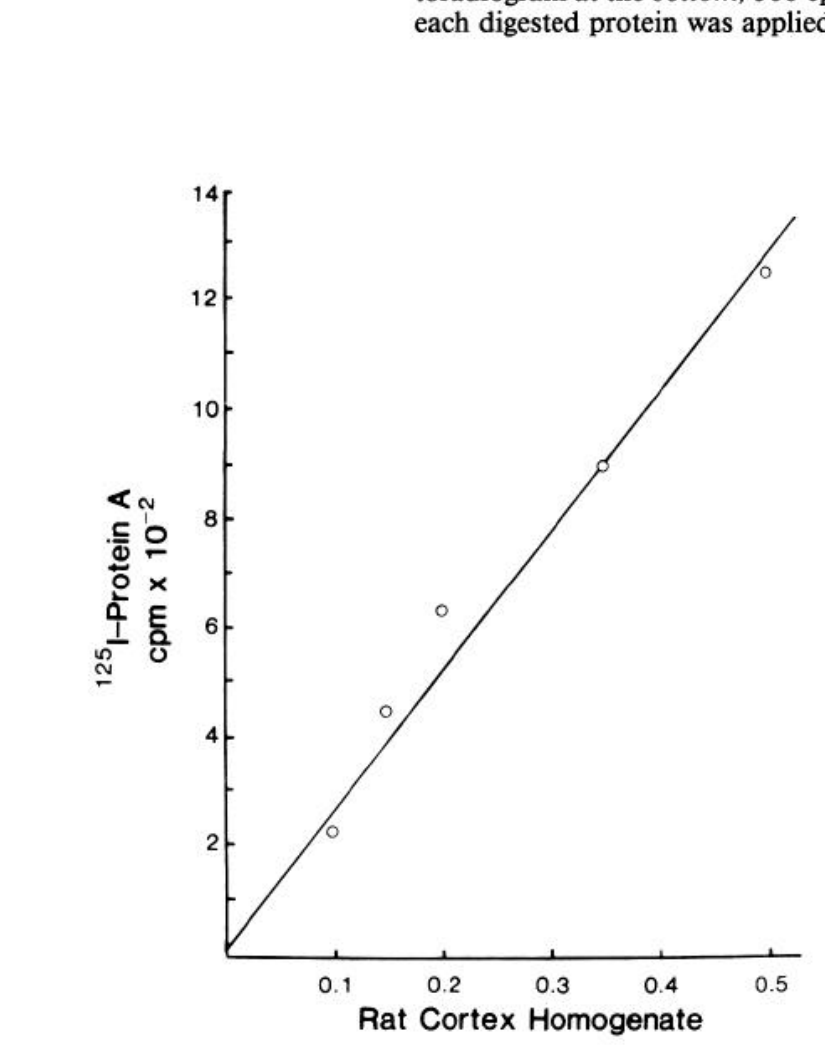

Figure 7. Standard curve depicting quantitative immunolabeling of protein IIIb in SDS-polyacrylamide gel. Various amounts of rat cerebral cortex homogenate were subjected to electrophoresis on SDS-polyacrylamide gels. The gels were incubated first with antibody raised against protein IIIb followed by incubation with ${ }^{125}$ I-protein A as described in Materials and Methods. 
Table 3. Regional distribution of proteins IIIa and IIIb in rat brain

\begin{tabular}{llll} 
& \multicolumn{3}{l}{ Relative specific activity } \\
\cline { 2 - 4 } Brain region & IIIa & IIIb & IIIa/IIIb \\
\hline Cerebral cortex & 48 & 100 & 0.48 \\
Hippocampus & 60 & 130 & 0.46 \\
Nucleus accumbens & 52 & 124 & 0.42 \\
Septum & 48 & 99 & 0.48 \\
Olfactory tubercle & 41 & 93 & 0.44 \\
Corpus striatum & 43 & 86 & 0.50 \\
Substantia nigra & 29 & 71 & 0.39 \\
Globus pallidus & 32 & 60 & 0.53 \\
Thalamus & 35 & 59 & 0.59 \\
Hypothalamus & 26 & 53 & 0.49 \\
Cerebellum & 22 & 43 & 0.51 \\
Olfactory bulb & 40 & 29 & 1.52 \\
Spinal cord & 10 & 21 & 0.48 \\
Pons/medulla & 9 & 19 & 0.47
\end{tabular}

Brain regions were dissected as described in Materials and Methods. Proteins IIIa and IIIb were then quantitated using immunolabeling in SDS-polyacrylamide gels. For each brain region, the labeling of protein IIIa and protein IIIb per milligram protein was expressed relative to the labeling of protein IIIb in rat cerebral cortex.

\section{Discussion}

In previous reports from this laboratory, 2 prominent phosphoproteins, proteins IIIa and IIIb, were shown to be phosphorylated in intact nerve cells by electrical stimulation, by depolarization in the presence of calcium, and by 8-bromocAMP (Forn and Greengard, 1978; Huang et al., 1982; Tsou and Greengard, 1982). In this report we present evidence indicating a marked degree of similarity between proteins IIIa and IIIb. These 2 proteins appear to possess significant structural homology since limited proteolysis of either protein with $S$. aureus V8 protease yielded a single, identically migrating 18,000 Da phosphopeptide fragment. When the 2 proteins were phosphorylated by the catalytic subunit of cAMP-dependent protein kinase and then subjected to limited proteolysis by trypsin and chymotrypsin, both proteins yielded only a single phosphopeptide, and these peptides comigrated when analyzed by 2 -di-

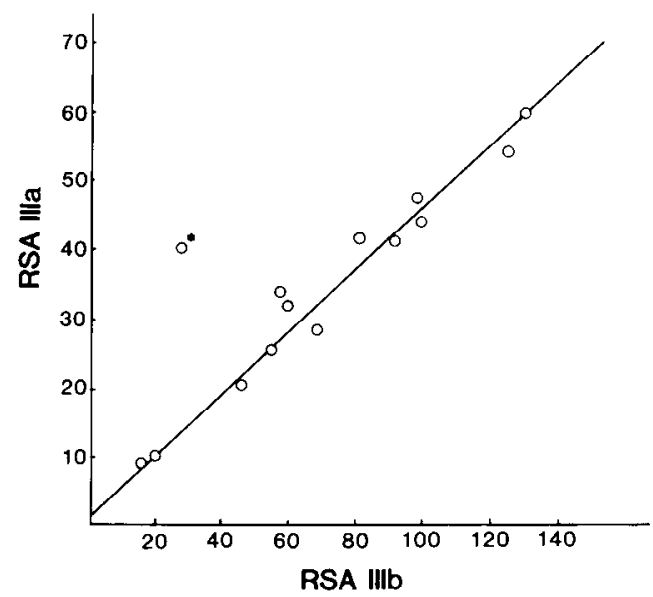

Figure 8. Comparison of the relative amounts of proteins IIIa and IIIb in various brain regions. The relative specific activity $(R S A)$ of protein IIIa in each brain region was plotted as a function of the RSA of protein IIIb in the corresponding region. Data taken from Table 3.
Table 4. Quantitation of the amounts of proteins IIIa and IIIb in subcellular fractions from rat brain

\begin{tabular}{lrrl} 
& \multicolumn{3}{c}{ Relative specific activity } \\
\cline { 2 - 4 } \multicolumn{1}{c}{ Subcellular fraction } & IIIa & IIIb & IIIa/IIIb \\
\hline Homogenate & 48 & 100 & 0.48 \\
Nuclear & 52 & 88 & 0.59 \\
Mitochondrial & 44 & 78 & 0.56 \\
Microsomal & 52 & 110 & 0.47 \\
Soluble & 11 & 22 & 0.50 \\
Synaptic plasma membrane & 112 & 271 & 0.42 \\
Synaptic vesicles & 316 & 700 & 0.45 \\
\hline
\end{tabular}

Subcellular fractions were prepared from cerebral cortex as described in Materials and Methods. Proteins IIIa and IIIb were then quantitated using immunolabeling in SDS-polyacrylamide gels. For each subcellular fraction the labeling of protein IIIa and protein IIIb per milligram protein was expressed relative to the labeling of protein IIIb in rat cerebral cortex homogenate (see Materials and Methods).

mensional peptide mapping. Additional evidence for the structural relatedness of these 2 proteins comes from data indicating that a number of poly- and monoclonal antibodies raised against protein IIIb exhibited virtually $100 \%$ cross-reactivity toward protein IIIa.

The structural homology between these 2 proteins (which differ in apparent $M_{r}$ by approximately 19,000 ) raises the possibility that protein IIIb might simply be a product of proteolytic degradation of protein IIIa. However, this seems unlikely for several reasons. First, the ratio of protein IIIa to protein IIIb remained essentially constant throughout the purification of the 2 proteins. Second, a cerebral cortex homogenate possessed no proteolytic activity capable of converting exogenous purified protein IIIa into protein IIIb (data not shown). Finally, when antibodies raised against protein IIIb are utilized to purify mRNA from rat brain polysomes and this purified $\mathrm{mRNA}$ is translated in vitro, both protein IIIa and protein IIIb are synthesized in a ratio similar to the ratio of protein IIIa and protein IIIb seen in adult tissue preparations (DeGennaro et al., 1983; also, S. Kanazir, M. Browning, and P. Greengard, unpublished observations).

The present study demonstrates that proteins IIIa and IIIb have similar tissue and brain region distributions and that the 2 proteins are associated with synaptic vesicles. These data suggest that the 2 proteins have similar roles in brain and that they may be involved in some aspect of synaptic vesicle function (e.g., stimulus-secretion coupling). The localization of these proteins in the adrenal medulla, a tissue that has a common embryological origin with neurons, is compatible with such a possibility. However, since the 2 proteins were not detected in other secretory tissues, an obligatory role in stimulus-secretion coupling in those other tissues can be excluded.

\section{References}

Adair, W., D. Jurivich, and U. Goodenough (1978) Localization of cellular antigens in sodium dodecyl sulfate polyacrylamide gels. J. Cell. Biol. 79: 281-285.

Beavo, J., P. Bechtel, and E. Krebs (1974) Preparation of homogeneous cyclic AMP-dependent protein kinase(s) and its subunits from rabbit skeletal muscle. Methods Enzymol. 38C: 299-309.

Browning, M. D., R. Huganir, and P. Greengard (1985) Protein phosphorylation and neuronal function. J. Neurochem. 45: 11-23.

Cleveland, D., S. Fischer, M. Kirschner, and U. Laemmli (1977) Peptide mapping by limited proteolysis in sodium dodecyl sulfate and analysis by gel electrophoresis. J. Biol. Chem. 252: 1102-1106.

Cotman, C. W., and D. Mathews (1971) Synaptic plasma membranes 
from rat brain synaptosomes: Isolation and partial characterization. Biochim. Biophys. Acta 249: 380-394.

DeCamilli, P., R. Cameron, and P. Greengard (1983a) Synapsin I (Protein I), a nerve terminal-specific phosphoprotein: I. Its general distribution in synapses of the central and peripheral nervous system demonstrated by immunofluorescence in frozen and plastic sections. J. Cell Biol. 96: 1337-1354.

DeCamilli, P., S. Harris, W. Huttner, and P. Greengard (1983b) Synapsin I (Protein I), a nerve terminal-specific phosphoprotein. II. Its specific association with synaptic vesicles demonstrated by immunocytochemistry in agarose-embedded synaptosomes. J. Cell Biol. 96: 1355-1388.

DeGennaro, L. S., S. D. Kanazir, W. C. Wallace, R. M. Lewis, and P. Greengard (1983) Neuron-specific phosphoproteins as models for neuronal gene expression. Cold Spring Harbor Symp. Quant. Biol. 48: 337-345.

Forn, J., and P. Greengard (1978) Depolarizing agents and cyclic nucleotides regulate the phosphorylation of specific neuronal proteins in rat cerebral cortex slices. Proc. Natl. Acad. Sci. USA 75: 51955199.

Gispen, W., and A. Routtenberg, eds. (1982) Progress in Brain Research, Vol. 55: Brain Phosphoproteins. Elsevier, Amsterdam.

Goelz, S., E. Nestler, B. Cherazi, and P. Greengard (1981) Distribution of protein $\mathrm{I}$ in mammalian brain as determined by a detergent-based radioimmunoassay. Proc. Natl. Acad. Sci. USA 78: 2130-2134.

Huang, C., M. Browning, and P. Greengard (1982) Purification and characterization of Protein IIIb, a mammalian brain phosphoprotein. J. Biol. Chem. 257: 6524-6528.

Huttner, W., and P. Greengard (1979) Multiple phosphorylation sites in Protein $I$ and their differential regulation by calcium and cyclic AMP. Proc. Natl. Acad. Sci. USA 76: 5402-5406.

Huttner, W., W. Schiebler, and P. Greengard (1983) Synapsin I (Pro- tein I), a nerve terminal specific phosphoprotein. III. Its specific association with synaptic vesicles studied in a highly purified synaptic vesicle preparation. J. Cell Biol. 96: 1374-1388.

Köhler, G., and C. Milstein (1975) Continuous cultures of fused cells secreting antibody of predefined specificity. Nature 256: 495-497.

Nestler, E., and P. Greengard (1982) Nerve impulses increase the state of phosphorylation of Protein I in rabbit superior cervical ganglion. Nature 296: 452-454.

Nestler E., and P. Greengard (1984) Protein Phosphorylation in the Nervous System, Wiley, New York.

O'Farrell, P. H. (1975) High resolution two dimensional electrophoresis of proteins. J. Biol. Chem. 250: 4007-4021.

O'Farrell, P. Z., H. Goodman, and P. H. O'Farrell (1977) High resolution two-dimensional electrophoresis of basic as well as acidic proteins. Cell 12: 1133-1142.

Rodnight, R. (1982) Aspects of protein phosphorylation in the nervous system with particular reference to synaptic transmission. In Brain Phosphoproteins, W. Gispen and A. Routtenberg, eds., Elsevier, Amsterdam.

Tsou, K., and P. Greengard (1982) Regulation of phosphorylation of Proteins I, IIIa, and IIIb in rat neurohypophysis in vitro by electrical stimulation and by neuroactive agents. Proc. Natl. Acad. Sci. USA 79: 6075-6079.

Ueda, T., and P. Greengard (1977) Adenosine 3':5'-monophosphateregulated phosphoprotein system of neuronal membranes. I. Solubilization, purification, and some properties of an endogenous phosphoprotein. J. Biol. Chem. 252: 5155-5163.

Walaas, S. I., A. C. Nairn, and P. Greengard (1983) Regional distribution of calcium- and cyclic adenosine $3^{\prime} 5^{\prime}$-monophosphate-regulated protein phosphorylation systems in mammalian brain. I. Particulate systems. J. Neurosci. 3: 291-301. 